Journal of Engineering and Applied Sciences 14 (Special Issue 7): 10023-10032, 2019

ISSN: 1816-949X

(C) Medwell Journals, 2019

\title{
Characterization and Synthesis of CR-Rubber Reinforced by Cadmium-Zinc Ferrite for Microwaves Absorption
}

\author{
Firas A'aid Najim and Wissam Adel Hussien \\ Department of Physics, College of Education, University of Al-Qadisiyah, \\ Al-Diwaniyah, Iraq
}

\begin{abstract}
The first phase of the process was carried out in two phases, the first process was to prepare material from nano-crystalline structure of $\mathrm{ZnFe}_{2} \mathrm{O}_{4}$ and $\mathrm{CdFe}_{2} \mathrm{O}_{4}$ depending on formula of $\mathrm{Cd}_{\mathrm{x}} \mathrm{Zn}_{1}$ ${ }_{x} \mathrm{Fe}_{2} \mathrm{O}_{4}$ combination by ratio ( $\mathrm{x}=0.9$ ) and mixing the compound of $\mathrm{ZnFe}_{2} \mathrm{O}_{4}$ with $\mathrm{CdFe}_{2} \mathrm{O}_{4}$ and they were prepared by using co-precipitation method because they give a great homogeneity to the powder particles. The second process used to blend the fractions by ratios (x) to the compound $\mathrm{Cd}_{0.9} \mathrm{Zn}_{0.1} \mathrm{Fe}_{2} \mathrm{O}_{4}$ with neoprene (Chloroprene Rubber, CR) by adding 3, 6 g. The XRD and Scanning Electron Microscopy (SEM) were investigated the structural properties for prepared samples and to determine length of unit cell, the results showed that ferrites had a cubic spinel structure and when increasing concentration (x) for the compound $\mathrm{Cd}_{\mathrm{x}} \mathrm{Zn}_{1-\mathrm{x}} \quad \mathrm{Fe}_{2} \mathrm{O}_{4}$ led to an increase the crystalline size and the distance between the crystalline surfaces, the ionic radius of the cadmium is greater than the ionic diameter of the zinc $\left(0.83 \mathrm{~A}^{\circ}\right)$. FESEM showed the increasing size of nanoparticles with increased concentration of Cadmium Ferrite $\left(\mathrm{CdFe}_{2} \mathrm{O}_{4}\right)$ in relation to compound $\mathrm{Cd}_{\mathrm{x}} \mathrm{Zn}_{1-\mathrm{x}} \mathrm{Fe}_{2} \mathrm{O}_{4}$, the elements of the ferrite structures showed by (EDS) and mixed compound of ferrite with the neoprene (Chloroprene Rubber, $\mathrm{CR}$ ) according to the weight ratios $3,6 \mathrm{~g}$. VNA was investigated within the X-band of the microwave $8-12 \mathrm{GHz}$, the best result was obtained by adding $6 \mathrm{~g}$ of neoprene (Chloroprene Rubber, CR) for attenuation microwaves. The real part of the dielectric constant and the imaginary part of the dielectric constant were calculated as a frequency function at the $\mathrm{X}$ beam within the microwave region. The real part of amplitude refers to the amount of energy from the external electric field stored in the material, the imaginary part refers to the scattered energy or loss of energy.
\end{abstract}

Key words: Cadmium-zinc ferrites, microwaves absorption, CR-rubber, co-precipitation, homogeneity, SEM

\section{INTRODUCTION}

Electrical industries were mainly based on iron and ferro-alloys to meet their magnetic requirements and the need to operate at high frequencies and standard techniques to reduce eddy currents losses and it was necessary to resort to what is new and special characteristics that leading to discover previously unknown materials (Spaldin, 2010). These materials are the materials of magnetic ceramics such as (ferrite) which has been developing to intervene in the construction of electrical circuits working at low frequencies and high (ferrite) is generally a set of iron oxides which are solid and fragile materials such as ceramics (Kombaiah et al., 2017) With different chemical structures and crystalline structure, all of which are semi-conductive magnetic materials ferrite has a high electrical resistivity of up to $10 \Omega$ and is accompanied by high magnetic permeability and constant isolation ranging from 10-15 as these quantities change by electric and magnetic sfields (Ismail et al., 2007). The increasing need for materials absorbs the energy of electromagnetic waves falling on them there are several applications of electromagnetic pads manufactured from the material of the material (Zhao et al., 2016), for example, avoid unwanted electromagnetic waves and generated internally in the devices and the prevention of electromagnetic noise as well as improve the performance of antennas and the construction of audio rooms and camouflage military places and aircraft and other military applications (Shtarkova and Dishovsky, 2009). The absorbent materials are classified, according to their technical and design specifications to several types, each with its uses and specials including narrow-band pipettes. These materials absorb a certain frequency band from the electromagnetic waves (Mahafza, 2013) and the material

Corresponding Author: Firas A’aid Najim, Department of Physics, College of Education, University of Al-Qadisiyah, Al-Diwaniyah, Republic of Iraq 


\section{J. Eng. Applied Sci., 14 (Special Issue 7): 10023-10032, 2019}

is used to absorb microwave waves within the band 8-12 GHz. After blending the ferrite with the rubber it is the types used neoprene (Chloroprene Rubber, CR) where the characteristics of this kind of rubber (Sindhu et al., 2002) and the thermal resistance for $C R$ rubber is approximately $121^{\circ} \mathrm{C}$. The cold elasticity is approximately $-40^{\circ} \mathrm{C}$ (Brydson, 1978). It contains high polar, paraffin and naphthenic oils but it is partially increased in aromatic solvents and decomposes during connection with engine fuel (Winspear, 1968). It has very low flammability. Winspear (1968) hydrochloric acid can be eliminated at high temperatures and therefore, metal oxides are added and have less insulating properties than non-polar rubber. When blending rubber with ferrites, it is composed of a surfactant that absorbs microwaves and improves the properties of the material (Koledintseva et al., 2006; Mutar, 2010).

\section{MATERIALS AND METHODS}

Preparation of $\mathbf{C d x Z n _ { 1 - x }} \mathrm{Fe}_{2} \mathbf{O}_{4}$ : The main material in this research is Cadmium-Zinc Ferrite $\left(\mathrm{CdxZn}_{1-\mathrm{x}} \mathrm{Fe}_{2} \mathrm{O}_{4}\right)$ and Chloroprene Rubber (CR) (Neoprene-type GRT). It was prepared by chemical co-precipitation method were it's a common to the addition of alkaline bases such as sodium hydroxide or ammonia to solutions containing metal ions in the composition of ferrite as the hydroxides of these metals or chlorides, the process was by mixing these materials with special weight ratios and then adding a distilled water to the mixing solution and combine them until we get a solution placed on a temperature $50^{\circ} \mathrm{C}$ for a period of time we added alkaline bases such as ammonia to the solution until $\mathrm{pH}$ will be between 12-8, the second process was burning the substances with temperature between $400-600^{\circ} \mathrm{C}$ for a period time of $6 \mathrm{~h}$ and leave it to cool until it reaches at room temperature and then grind it and burn it for $6 \mathrm{~h}$ at a temperature $800-1100^{\circ} \mathrm{C}$.

Tests for the resulting ferrite material X-Ray Diffraction XRD, FE SEM and EDS. Thus, we prepared a rubber paste of CR-rubber and mixing method using (Comerio Ercole Busto Avsizo Company) instrument, it contains two rolls with diameter 150 and $300 \mathrm{~mm}$ length. The materials were added according to Table 1 the rubber was inserted between the rollers several times with decreasing the distance between the two rollers material was added, respectively with continuous mixing. This process was carried out at laboratory temperature, the rubber paste was then ready to prepare a layer of GRT-ferrite as L $=20 \mathrm{~cm}, \mathrm{~W}=20 \mathrm{~cm}, \mathrm{~h}=2 \mathrm{~mm}$ ) and the attenuation was measured with frequencies 8-12 Ghz using (Anritsu-S4642A 10 MHz-20 GHz vector-networkanalyzer.
Table 1: Synthesis of rubber paste and ferrite

\begin{tabular}{lcc}
\hline Materials & $\begin{array}{c}\text { Parts Per Hundred } \\
\text { of Rubber (PPHR) }\end{array}$ & $\begin{array}{c}\text { Weight of } \\
\text { embryos }(100 \mathrm{~g})\end{array}$ \\
\hline Rubber GRT & 100 & 63.37 \\
6PPD & 1 & 0.62 \\
Stearic acid & 1 & 0.62 \\
Zinc oxide & 5 & 3.12 \\
MBTS & 0.5 & 0.31 \\
Aromatic oil & 10 & 6.37 \\
HAF326 & 40 & 25.37 \\
CdxZn $_{1-\mathrm{x}} \mathrm{Fe}_{2} \mathrm{O}_{4}$ & 3,6 & 3,6 \\
\hline
\end{tabular}

\section{RESULTS AND DISCUSSION}

Structural and morphological properties XRD: It was found that the ferrite compounds $\mathrm{ZnFe}_{2} \mathrm{O}_{4}$ and $\mathrm{CdFe}_{2} \mathrm{O}_{4}$ were tested at $\mathrm{X}$-ray diffraction after initial combustion at a temperature $600^{\circ} \mathrm{C}$ and the process of final combustion at $900^{\circ} \mathrm{C}$, found that the composite of the ferrite $\mathrm{ZnFe}_{2} \mathrm{O}_{4}$ is identical to the standard card (00-022-1012 ICDD) and ferrite of $\mathrm{CdFe}_{2} \mathrm{O}_{4}$ also identical with the standard card (ICDD 00-022-1063) were showing that the diffraction peaks at the crystalline levels (111, 220, 311, 222, 400, $331,422,511,440,531,620,533,622,444)$ which confirms to be as spinel ferrite based on FCC lattice for all samples. This indicates that the preparation method ensures the incorporation of positive ions in the spinel structure and after mixing the two compounds to form the compound $\mathrm{Cd}_{0 \cdot 9} \mathrm{Zn}_{0 \cdot 1} \mathrm{Fe}_{2} \mathrm{O}_{4}$, XRD was tested for each compound as shown in Fig. 1 and 2: we calculate parametrs of $\left(\mathrm{d}_{\mathrm{hk}}\right)$, lattice constant, crystalline volume, stress and the density of dissociationat the highest peak (311), the calculations were found from X-ray diffraction showing that the lattice splicing constant, ferrite compound of $\mathrm{Cd}_{0 \cdot 0} \mathrm{Zn}_{1.0} \mathrm{Fe}_{2} \mathrm{O}_{4}$ equal to (8.425887647) and the lattice splicing constant (a) ferrite compound of $\mathrm{Cd}_{1.0} \mathrm{Zn}_{0 \cdot 0} \mathrm{Fe}_{2} \mathrm{O}_{4}$ equal to 8.916407702. After blending the composite compounds and get the composite $\mathrm{Cd}_{0.9} \mathrm{Zn}_{0.1} \mathrm{Fe}_{2} \mathrm{O}_{4}$. It becomes a fixed lattice 8.916407702 to the highest point as shown in Fig. 3 and 4. In addition, the average size of crystal and crystalline surfaces is increased by increasing the concentration of cadmium ferrite $\mathrm{Cd}_{1.0} \mathrm{Zn}_{0 \cdot 0} \mathrm{Fe}_{2} \mathrm{O}_{4}$ due to the difference in the ionic radius of both cadmium and zinc. The ionic radius of zinc $0.83 \mathrm{~A}$ and cadmium $0.99 \mathrm{~A}$ and Table 2 shows the calculations and information derived from the $\mathrm{X}$-Ray Diffraction test (XRD).

SEM and EDS: FESEM was investigated for the composite ferrite samples $\mathrm{Cd}_{\mathrm{X}} \mathrm{Zn}_{1-\mathrm{X}} \mathrm{Fe}_{2} \mathrm{O}_{4}$ which can give clear information on particle size and crystalline form of nanostructures. Figure 4 and 5 show the compound structures with ratio $\mathrm{X}=0.0$ for the compound $\mathrm{Cd}_{0.0} \mathrm{Zn}_{1.0}$ $\mathrm{Fe}_{2} \mathrm{O}_{4}$ and $\mathrm{x}=1.0$ for $\mathrm{Cd}_{1 \cdot 0} \mathrm{Zn}_{0 \cdot 0} \mathrm{Fe}_{2} \mathrm{O}_{4}$ as we seen it gives a clear picture for prepared samples. The crystal size for cadmium ferrite is between $210-108.8 \mathrm{~nm}$ and crystal size 
J. Eng. Applied Sci., 14 (Special Issue 7): 10023-10032, 2019

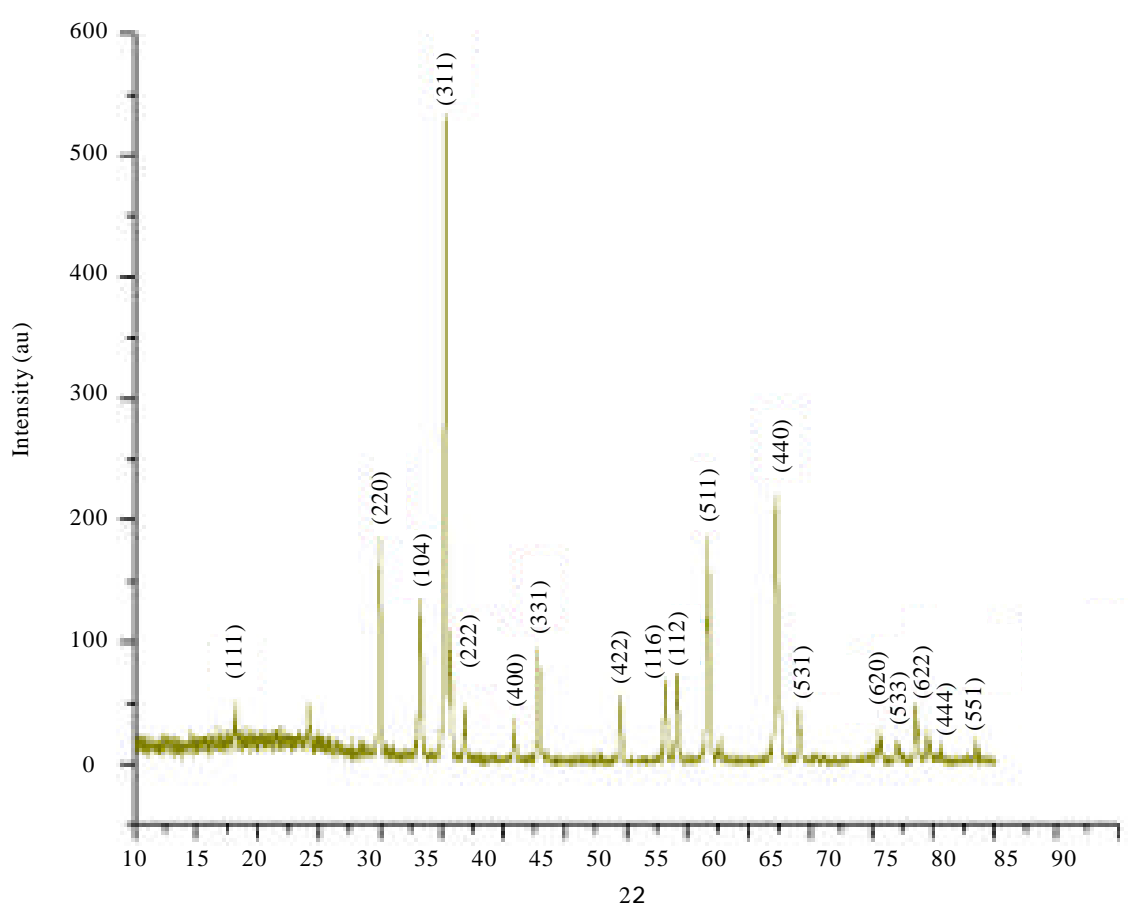

Fig. 1: X-ray diffraction for the compound $\mathrm{ZnFe}_{2} \mathrm{O}_{4}$ at $900^{\circ} \mathrm{C}$

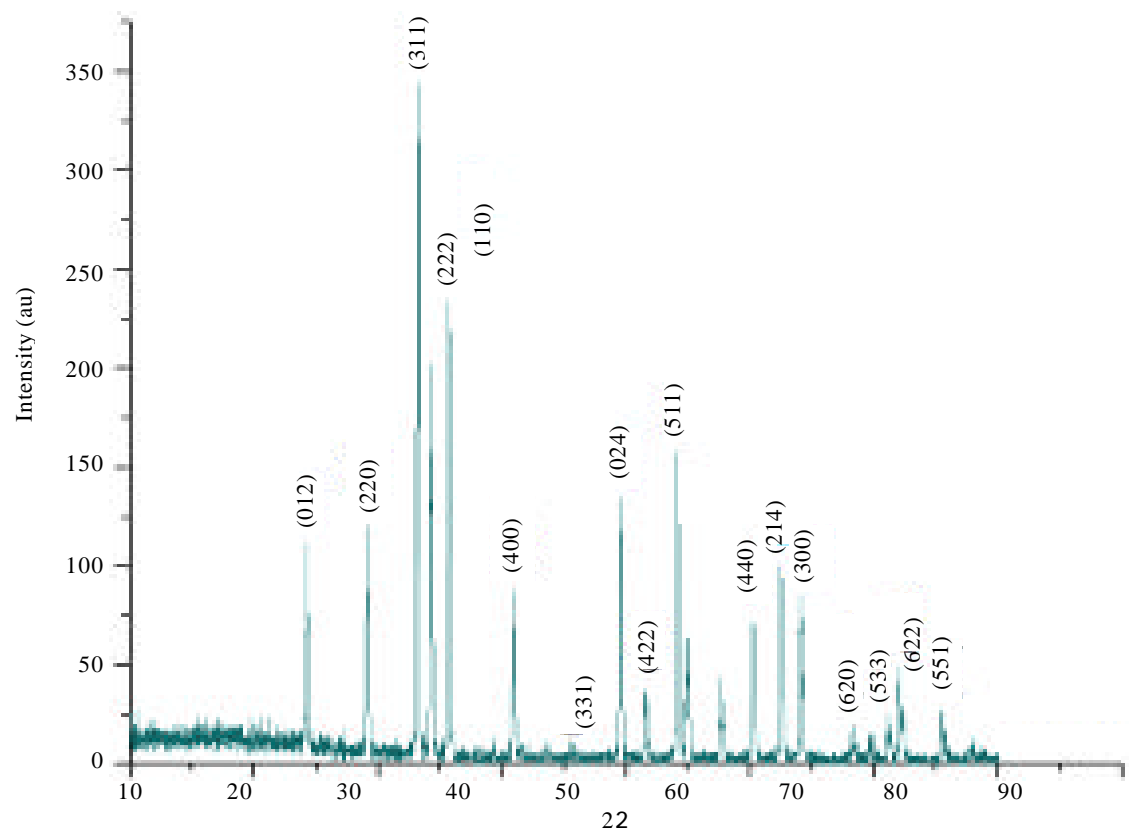

Fig. 2: X-ray diffraction for the compound $\mathrm{CdFe}_{2} \mathrm{O}_{4}$ at $900^{\circ} \mathrm{C}$

Table 2: The information extracted from the XRD examination

\begin{tabular}{lllcccc}
$\mathrm{X}$ & $\mathrm{Cd}_{\mathrm{x}} \mathrm{Zn}_{1-\mathrm{X}} \mathrm{Fe}_{2} \mathrm{O}_{4}$ & $\mathrm{~d}=\mathrm{n} \lambda / 2 \sin \theta$ & $\mathrm{a}=\mathrm{d}_{\mathrm{hal}} \times \mathrm{vh}^{2}+\mathrm{k}^{2}+\mathrm{l}^{2}$ & $\mathrm{D}=\mathrm{K} . \lambda / \mathrm{B} \cos \theta$ & $\Sigma=\mathrm{B} \cos \theta / 4$ & $\mathrm{~S}=1 / \mathrm{D}^{2}\left(\mathrm{~A}^{\circ}\right)$ \\
\hline 0.0 & $\mathrm{Cd}_{0.0} \mathrm{Zn}_{1.0} \mathrm{Fe}_{2} \mathrm{O}_{4}$ & 2.540501319 & 8.425887647 & 364.2269352 & 0.000951676 & $7.538 \mathrm{E}-0600$ \\
1.0 & $\mathrm{Cd}_{1.0} \mathrm{Zn}_{0.0} \mathrm{Fe}_{2} \mathrm{O}_{4}$ & 2.688398716 & 8.916407702 & 453.8272308 & 0.000763784 & $4.85533 \mathrm{E}-06$ \\
0.9 & $\mathrm{Cd}_{0.9} \mathrm{Zn}_{0.1} \mathrm{Fe}_{2} \mathrm{O}_{4}$ & 2.688398716 & 8.916407702 & 981.5383080 & 0.000353146 & $1.03797 \mathrm{E}-06$ \\
\hline
\end{tabular}




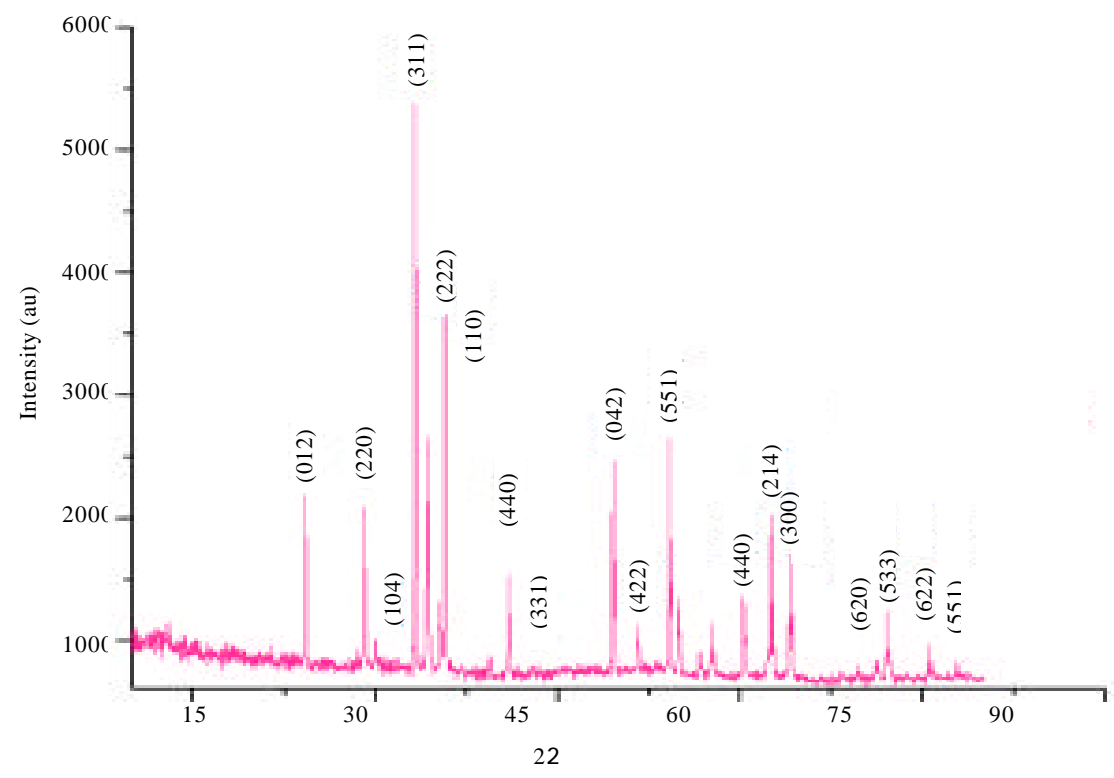

Fig. 3: The effect of the increase of ferrite cadmium for the ferrite compound $\mathrm{Cd}_{0.9} \mathrm{Zn}_{0 \cdot 1} \mathrm{Fe}_{2} \mathrm{O}_{4}$

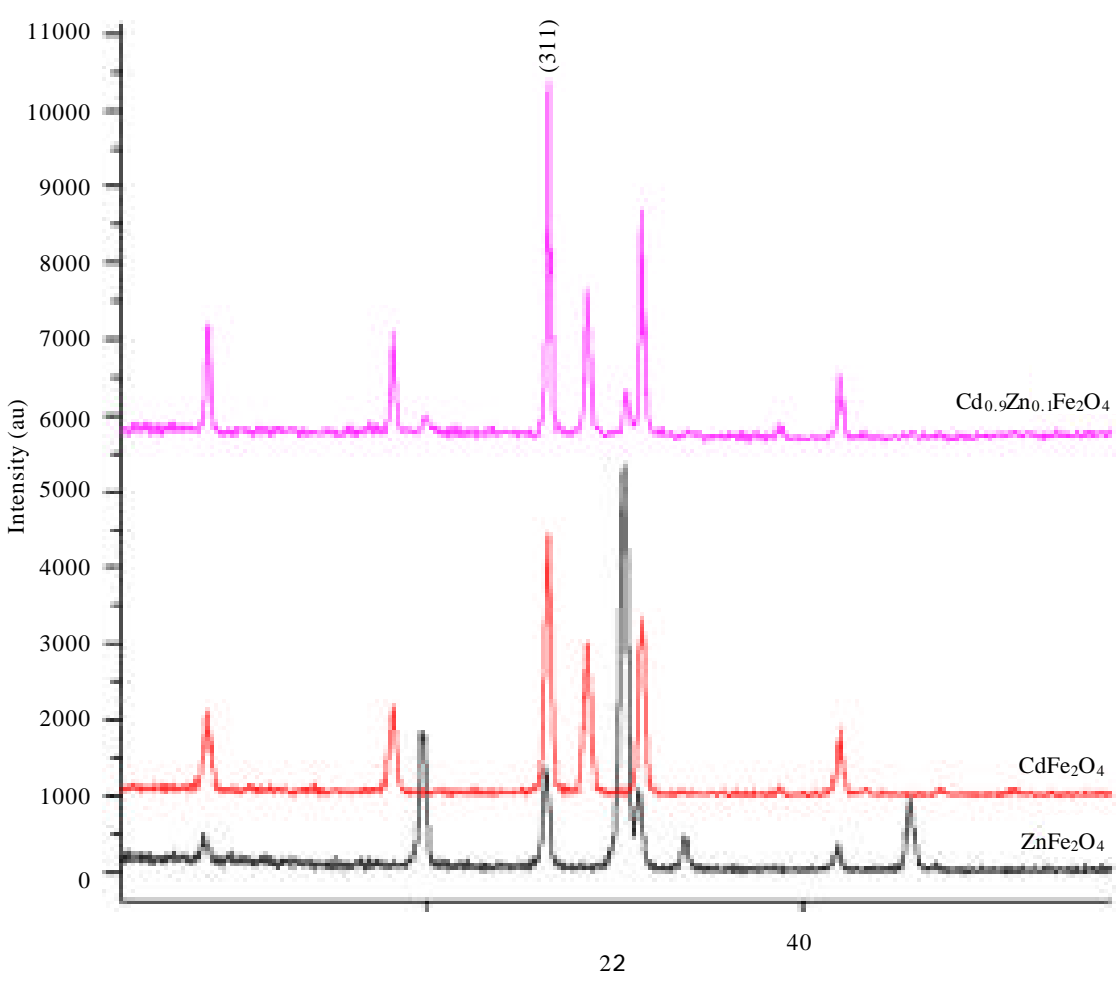

Fig. 4: The effect of the increase of ferrite cadmium for the ferrite compounds

for zinc ferrite between 79.2-47.14 nm the results shows that crystal size of cadmium ferrite is greater than zinc ferrite because the ionic radius of cadmium is greater than the ionic radius of zinc which is $0.83^{\circ} \mathrm{A}$ as shown in Fig. 5 and 6 when ratio $X=0.9$ for compound
$\mathrm{Cd}_{0 \cdot 9} \mathrm{Zn}_{0.1} \mathrm{Fe}_{2} \mathrm{O}_{4}$ note that crystal size increase significantly as shown in Fig. 7 and 8 was noted for having both compounds nanoparticles prepared as described as different particles from each other in size clearly. The crystal size increase and ranging between $52.12-463.6 \mathrm{~nm}$ 
to rate size of nanoparticles and increases whenever replace the Zinc ions $\left(\mathrm{Zn}^{+2}\right)$ Cadmium ions $\left(\mathrm{Cd}^{+2}\right)$ in the crystal lattice. The results of X-ray tests are consistent with those obtained from the FESEM test. The composition and chemical elements of the ferrite compounds were determined using the $\mathrm{X}$-ray Dispersion

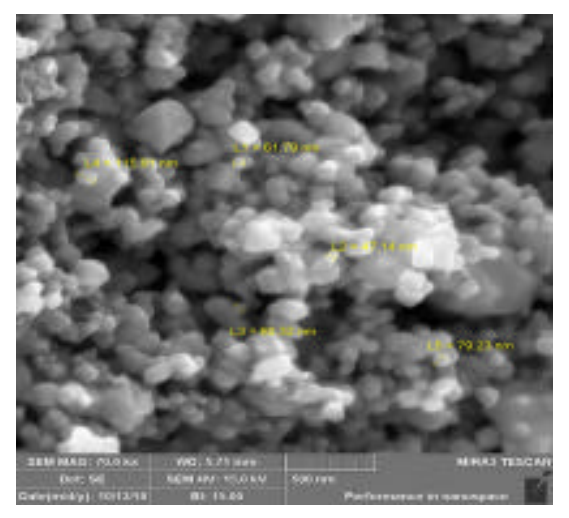

Fig. 5: FESEM images of the 0.0 ratios of the compound $\mathrm{Cd}_{\mathrm{X}} \mathrm{Zn}_{1-\mathrm{X}} \mathrm{Fe}_{2} \mathrm{O}_{4}$

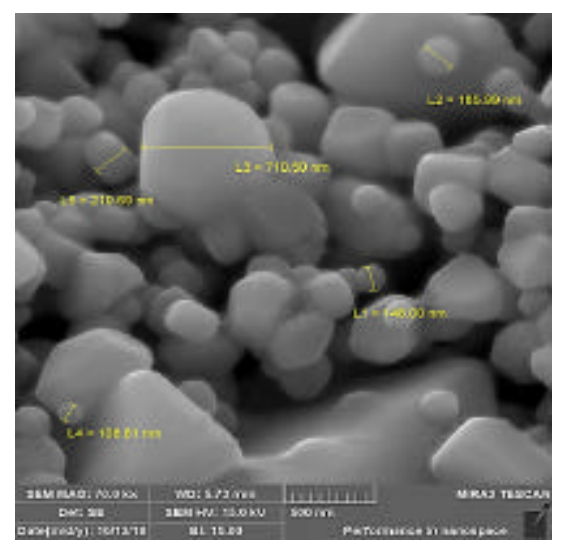

Fig. 6: FESEM images of the 1.0 ratios of the compound $\mathrm{Cd}_{\mathrm{X}} \mathrm{Zn}_{1-\mathrm{X}} \mathrm{Fe}_{2} \mathrm{O}_{4}$
Energy (EDS). The first ratio of $\mathrm{X}=0.0$ of the compound $\mathrm{Cd}_{0.0} \mathrm{Zn}_{1.0} \mathrm{Fe}_{2} \mathrm{O}_{4}$ was obtained and the EDS spectra revealed the presence of the following elements only (iron, zinc, carbon and oxygen) as shown in Fig. 9 and 10 also, EDS spectra for prepared samples with ratio $\mathrm{X}=0.9 \mathrm{Cd}_{0.9} \mathrm{Zn}_{0.1} \mathrm{Fe}_{2} \mathrm{O}_{4}$ as shown in Fig. 11. The EDS

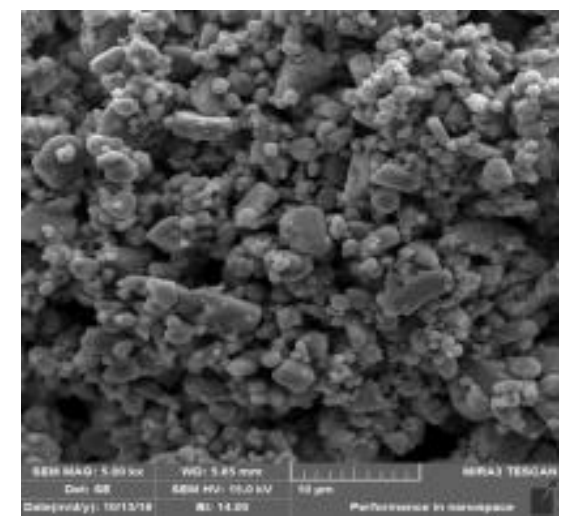

Fig. 7: FESEM images of the 0.9 ratio of the compound $\mathrm{Cd}_{\mathrm{X}} \mathrm{Zn}_{1-}{ }_{\mathrm{X}} \mathrm{Fe}_{2} \mathrm{O}_{4}$ (performance in nanospace)

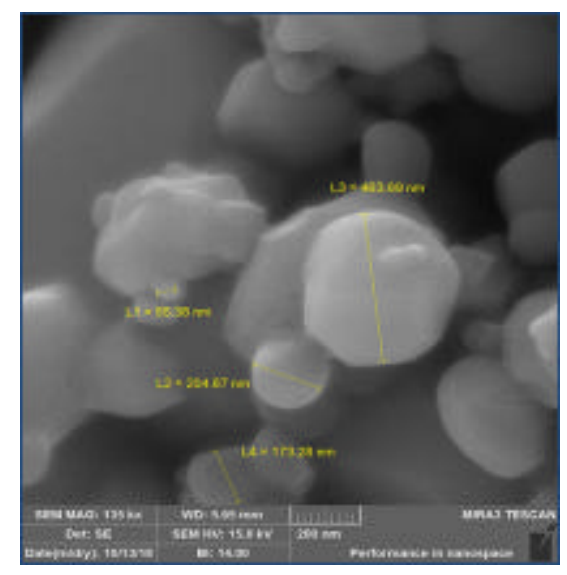

Fig. 8: FESEM images of the 0.9 ratio of the compound $\left.\mathrm{Cd}_{\mathrm{X}} \mathrm{Zn}_{1-}{ }^{-} \mathrm{Fe}_{2} \mathrm{O}_{4}, 200 \mathrm{~nm}\right)$

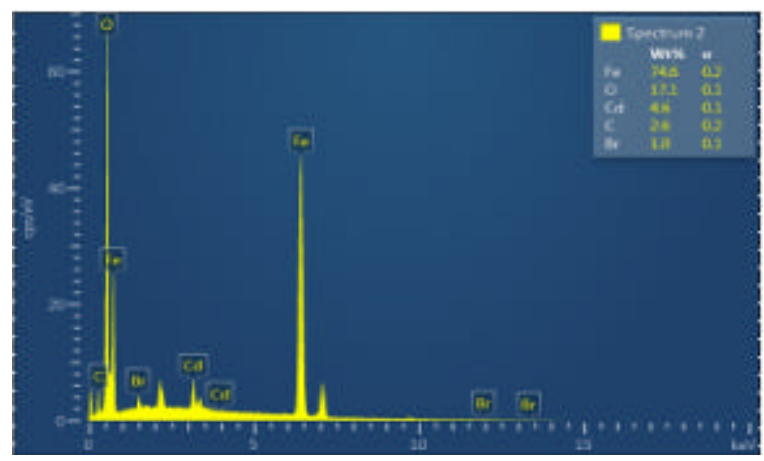

Fig. 9: Examination EDS of the compound $\mathrm{Cd}_{1.0} \mathrm{Zn}_{0.0} \mathrm{Fe}_{2} \mathrm{O}_{4}$ 


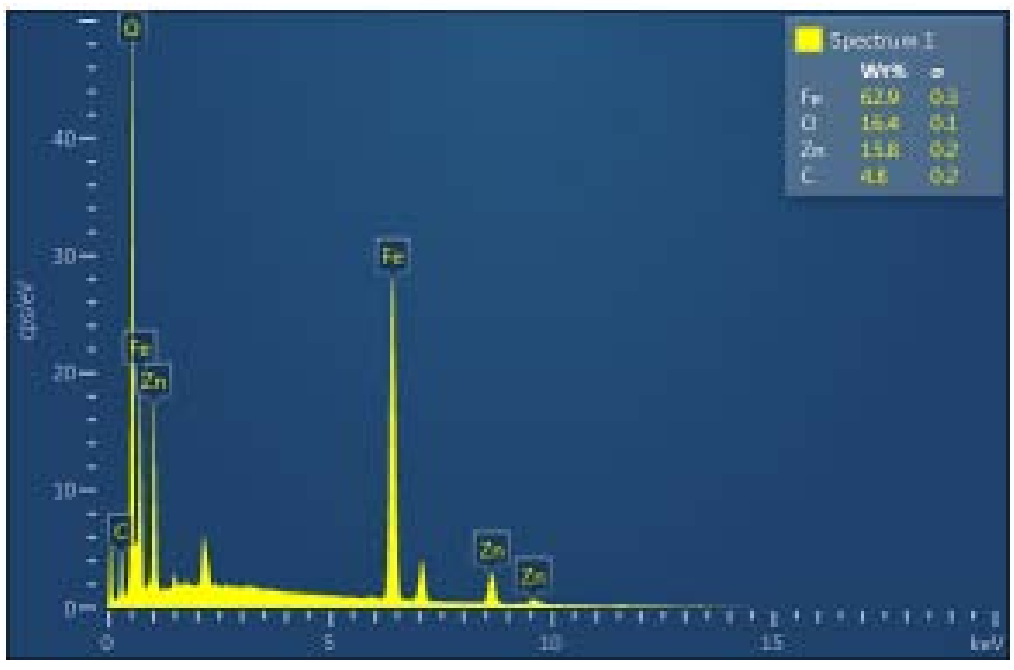

Fig. 10: Examination EDS of the compound $\mathrm{Cd}_{0.0} \mathrm{Zn}_{1.0} \mathrm{Fe}_{2} \mathrm{O}_{4}$

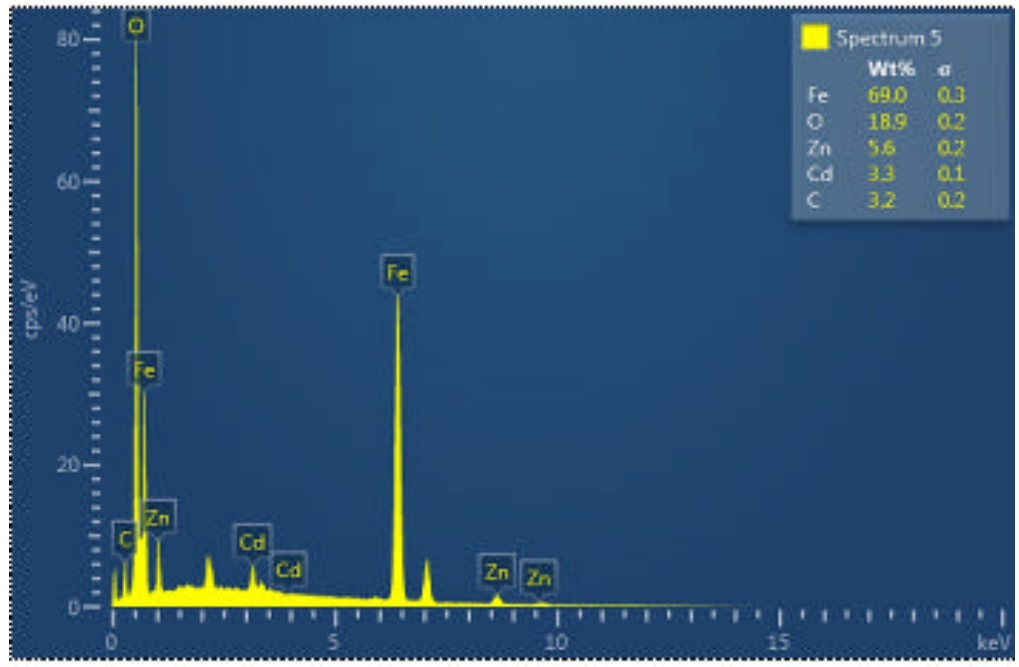

Fig. 11: Examination EDS of the compound for $\mathrm{Cd}_{0.9} \mathrm{Zn}_{0.1} \mathrm{Fe}_{2} \mathrm{O}_{4}$

Table 3: Percentage of constituent elements of compounds

\begin{tabular}{|c|c|c|c|c|c|c|c|c|c|c|c|c|}
\hline $\mathrm{X}$ & $\mathrm{Cd}_{\mathrm{x}} \mathrm{Zn}_{1-\mathrm{x}} \mathrm{Fe}_{2} \mathrm{O}_{4}$ & $\mathrm{O}$ & $\sigma$ & $\mathrm{Fe}$ & $\sigma$ & $\mathrm{Zn}$ & $\sigma$ & $\mathrm{Cd}$ & $\sigma$ & $\mathrm{C}$ & $\sigma$ & Total \\
\hline 0.0 & $\mathrm{Cd}_{0.0} \mathrm{Zn}_{1.0} \mathrm{Fe}_{2} \mathrm{O}_{4}$ & 16.4 & 0.1 & 62.9 & 0.3 & 15.8 & 0.2 & - & - & 4.8 & 0.2 & 100 \\
\hline 1.0 & $\mathrm{Cd}_{1.0} \mathrm{Zn}_{0.0} \mathrm{Fe}_{2} \mathrm{O}_{4}$ & 17.1 & 0.1 & 74.6 & 0.2 & - & - & 4.6 & 0.1 & 2.6 & 0.2 & 100 \\
\hline 0.9 & $\mathrm{Cd}_{0.9} \mathrm{Zn}_{0.1} \mathrm{Fe}_{2} \mathrm{O}_{4}$ & 19.9 & 0.2 & 56.5 & 0.3 & 17.9 & 0.2 & 0.4 & 0.1 & 5.4 & 0.2 & 100 \\
\hline
\end{tabular}

spectra revealed that only the following elements (iron, cadmium, carbon, oxygen and zinc) were found as shown in Table 3, since, the atomic ratio of oxygen ranges from 16.4-19.9, iron ranges from 56.5-62.9 and carbon 4.8-5.4 while zinc decreases and cadmium increases by replacing cadmium with zinc depending on chemical method of co-precipitation.

Reflection coefficient and loss of reflection and attenuation and complex permittivity: The reflection coefficient for prepared samples as a function of frequency (f) was investigated as shown in Fig. 12 the variation of reflection coefficient for compounds when adding $3 \mathrm{~g}$ of ferrite to neoprene (Chloroprene Rubber, $\mathrm{CR}$ ) to mixed compound $\mathrm{Cd}_{\mathrm{x}} \mathrm{Zn}_{1-\mathrm{x}} \mathrm{Fe}_{2} \mathrm{O}_{4}$ shows a lower reflectivity at value 0.046 at $9.82 \mathrm{Ghz}$ and when adding $6 \mathrm{~g}$ of ferrite to (CR) rubber as shown in Fig.12 the mean value of the reflection coefficient 0.019 for $\mathrm{x}=0.9$ at frequency $8.87-9.233 \mathrm{GHz}$ as we seen the difference of addition 3 and $6 \mathrm{~g}$ from ferrite compound to (CR) rubber. We observe a greater reduction in the reflection coefficient by increasing the ferrite to rubber within the 
J. Eng. Applied Sci., 14 (Special Issue 7): 10023-10032, 2019

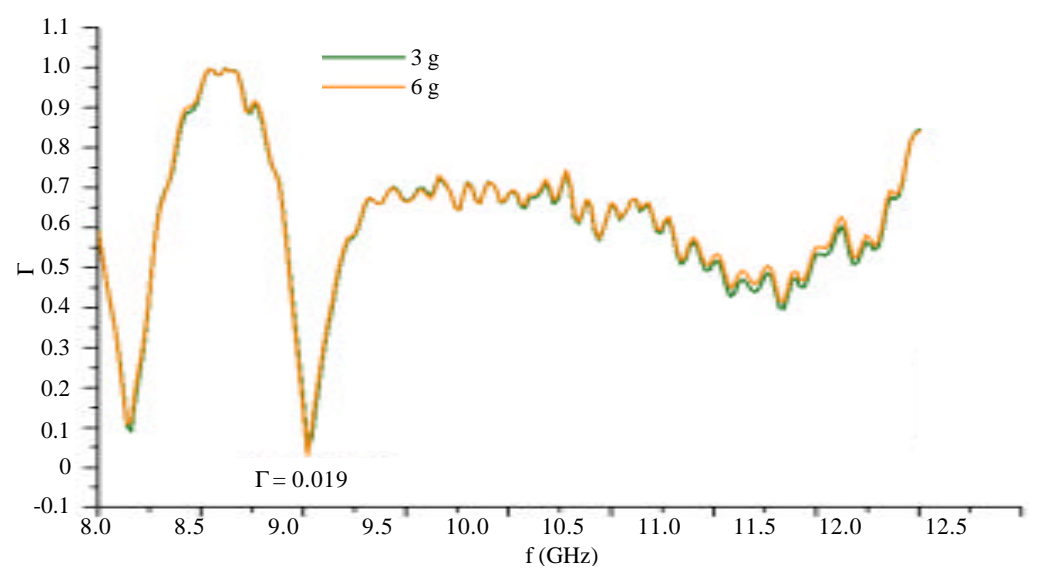

Fig. 12: Reflection coefficient

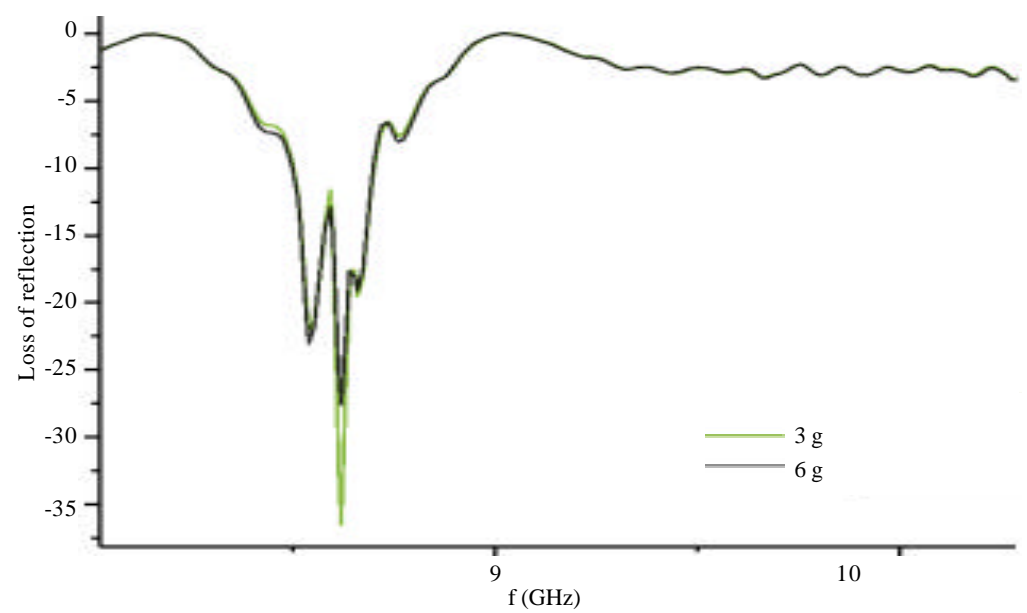

Fig. 13: Loss of reflection

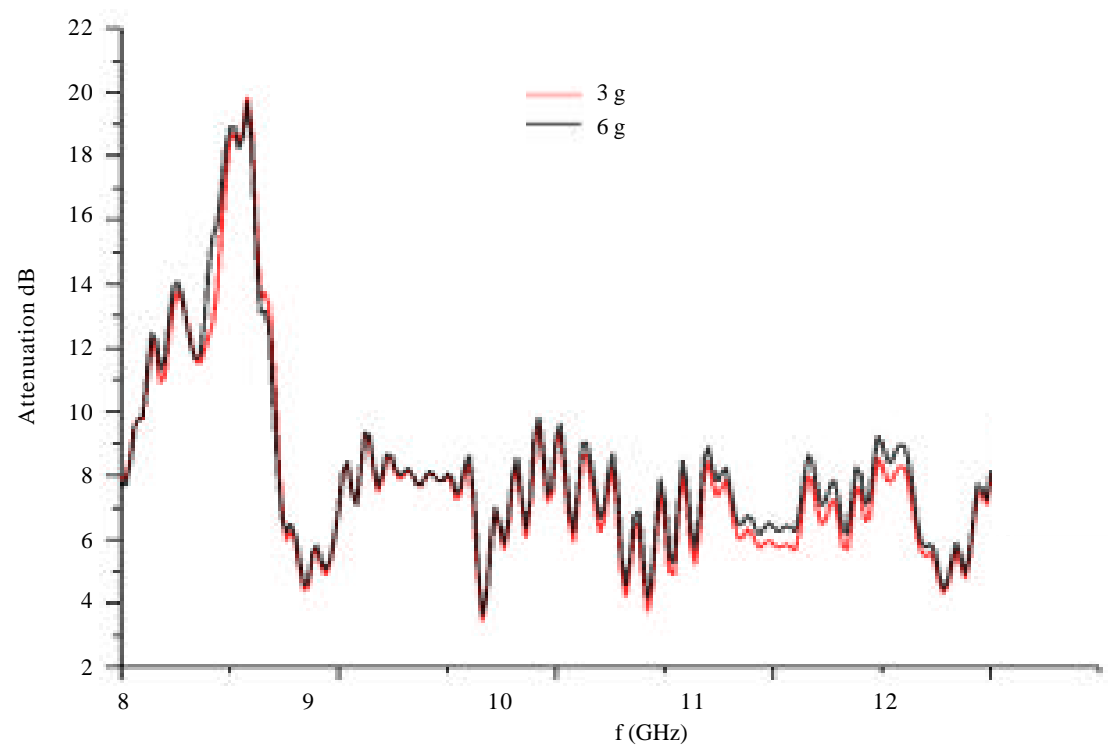

Fig. 14: Attenuation for 3, $6 \mathrm{~g}$ 


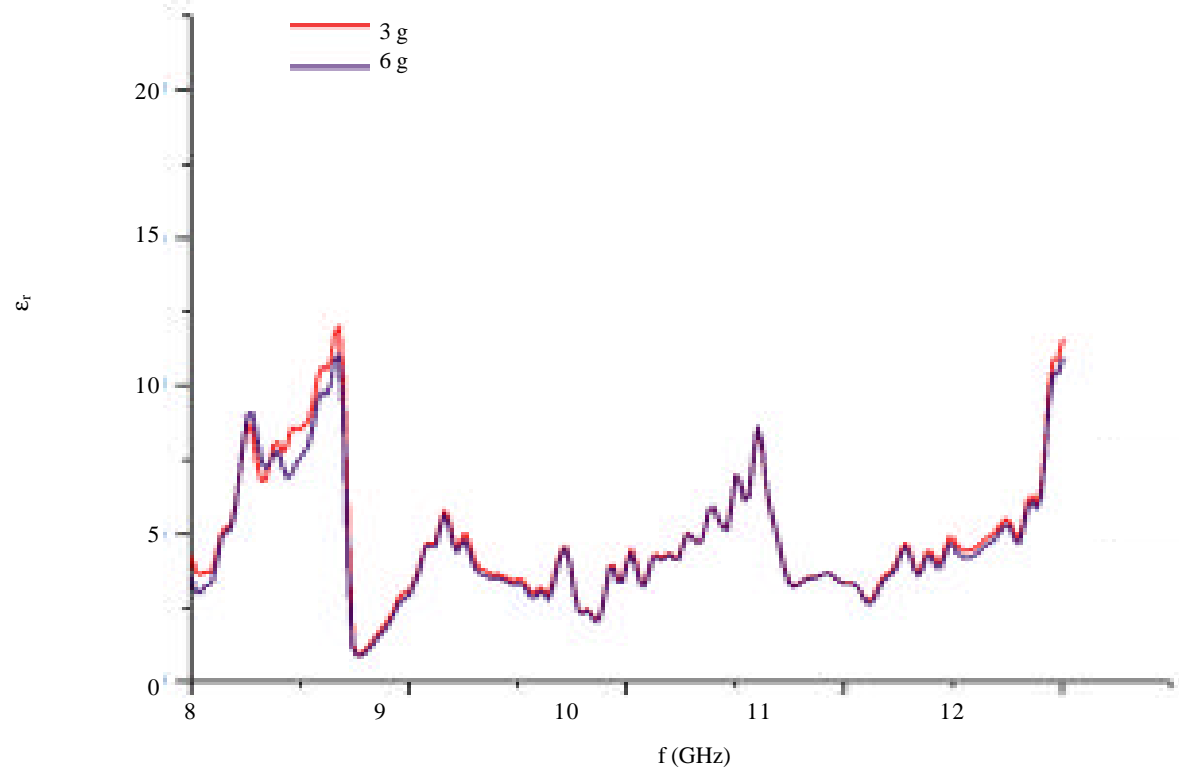

Fig. 15: The permittivity for $3,6 \mathrm{~g}$

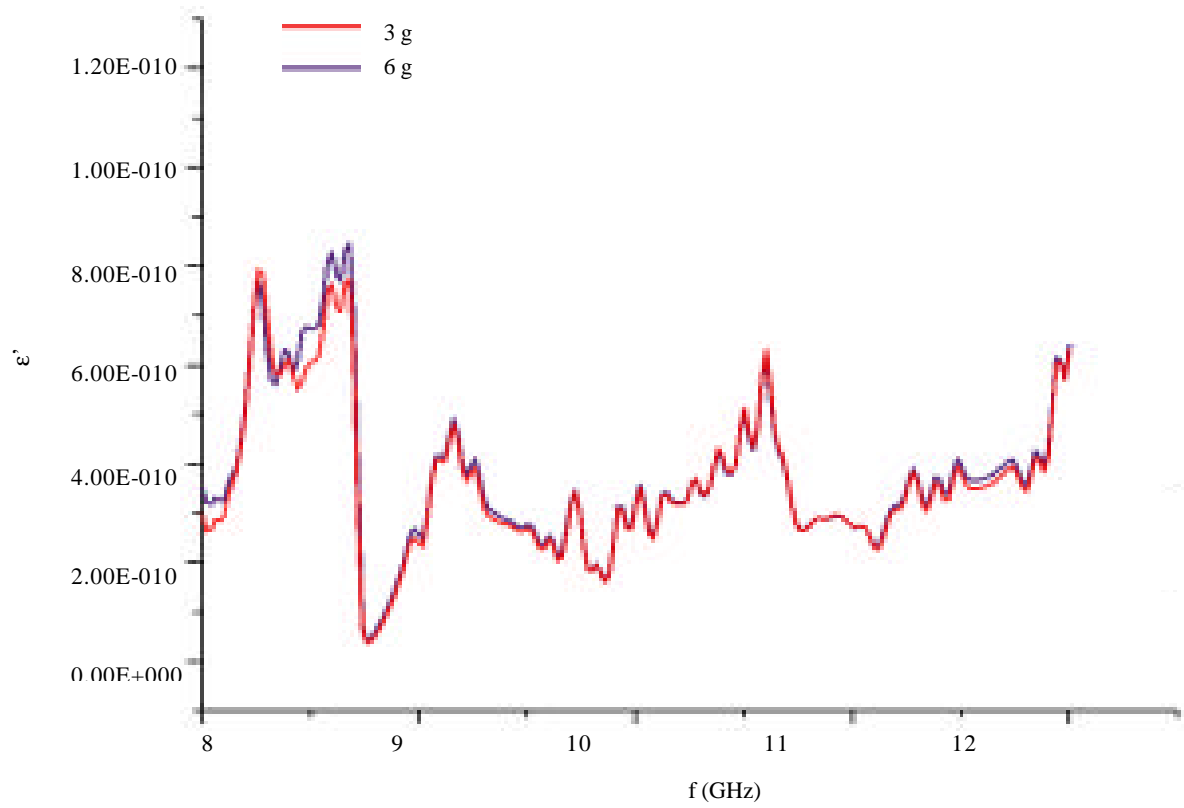

Fig. 16: The real dielectric constant

frequency 8.871-9.307 GHz which achieved the lowest value of the reflection coefficient. The lower reflection coefficient met a greater absorption value of the material and loss of reflection was investigated as shown in Fig. 13 where the lower value of reflection coefficient also met higher absorbent value for materials, the greatest value for loss of reflectivity at the ratio $\mathrm{x}=0.9$ is $-36.480 \mathrm{~dB}$ at the frequency $8.620 \mathrm{GHz}$. When adding $6 \mathrm{~g}$ of ferrite to CR rubber at $\mathrm{x}=0.9$ will be a largest value of loss of reflectivity $27.550 \mathrm{~dB}$ at $8.620 \mathrm{GHz}$ as in Fig. 13. This change in the reflection loss coefficient is due to microwave absorption. It was observed that the highest attenuation value for all bands at 18.8-40.8 Ghz is 19.7-19.3 dB. Figure 14 indicates attenuation values by adding $6 \mathrm{~g}$ of ferrite to (CR) rubber, note that the highest attenuation value for all bands within the range 


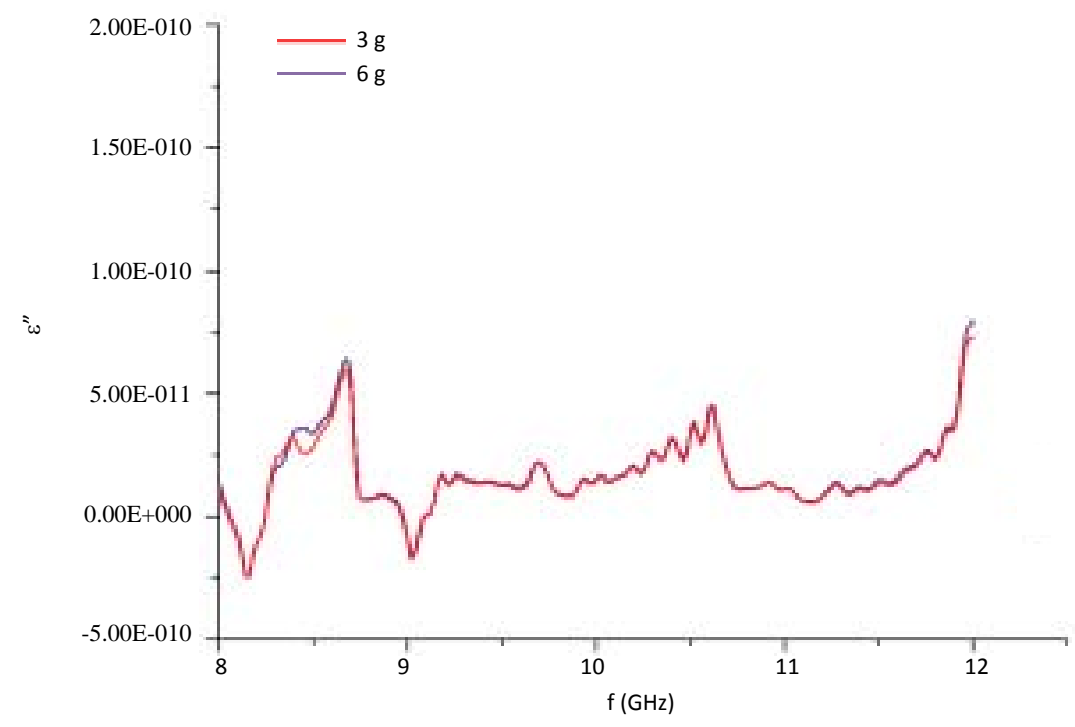

Fig. 17: The imaginary dielectric constant

8.38-8.87 Ghz is $20.7-19.4 \mathrm{~dB}$. The composite permittivity of the prepared samples was calculated as a function of the frequency for adding $3 \mathrm{~g}$ of the ferrite to (CR) rubber. The permittivity value at $\mathrm{x}=0.9$ is 12.02 at $8.075 \mathrm{GHz}$ and for adding $6 \mathrm{~g}$ of the ferrite to (CR) rubber the permittivity is 11.23 at $8.075 \mathrm{GHz}$ as in Fig. 15. The actual part of the dielectric constant and the imaginary part of the dielectric constant as a function of the frequency at the $\mathrm{X}$ band within the microwave region indicate the real part of the amplitude to the amount of energy from the external electric field stored in the material where dielectric constant at $3 \mathrm{~g}$ was $8.53 * 10^{-11}$ and at $6 \mathrm{~g}$ was $8.02 * 10^{-11}$, we notice an increase in value of the dielectric. The real part which refers to the amount of energy stored as shown in Fig. 16. The imaginary part refers to the scattered energy or loss of energy which is a measure of the loss of material for the true external electric field. The value of the imaginary insulation at the addition of $3 \mathrm{~g}$ of the ferrite to the (CR) rubber with the highest value at $6.47 * 10^{-11}-2.38 * 10^{-11}$ and when adding $6 \mathrm{~g}$ of ferrite the material became $6.001 * 10^{-11}$ $2.33^{*} 10^{-11}$ which refers to the loss of energy as in Fig. 17.

\section{CONCLUSION}

The process of preparation of cadmium and zinc ferrite is a very important process, found the composition of compound $\mathrm{Cd}_{\mathrm{X}} \mathrm{Zn}_{1-\mathrm{X}} \mathrm{Fe}_{2} \mathrm{O}_{4}$ when adding $\mathrm{X}=0.9$ of cadmium ferrite to zinc will increase the crystal size of compound $\mathrm{Cd}_{0.9} \mathrm{Zn}_{0.1} \mathrm{Fe}_{2} \mathrm{O}_{4}$ and when the compound $\mathrm{Cd}_{\mathrm{X}} \mathrm{Zn}_{1-\mathrm{X}} \mathrm{Fe}_{2} \mathrm{O}_{4}$ mixed with (CR) rubber by adding 3 and $6 \mathrm{~g}$ from ferrite we noticed the reflection coefficient was decreases as the amount of ferrite increases, so, we get a substance with high absorption of microwaves and with high attenuation. The higher the amount of ferrite to the (CR) rubber increases the absorption of the material. The addition of the ferrite to the rubber improves the properties of the material and the ability to absorb the microwave waves.

\section{REFERENCES}

Brydson, J.A., 1978. Rubber Chemistry. Elsevier Applied Science Publishers, London, ISBN:9780853347798, Pages: 462.

Ismail, H., S.T. Sam, M.A.F. Noor and A.A. Bakar, 2007. Properties of ferrite-filled natural rubber composites. Polym. Plast. Technol. Eng., 46: 641-650.

Koledintseva, M., P.C. Ravva, J. Drewniak, A.A. Kitaitsev and A.A. Shinko, 2006. Engineering of ferrite-graphite composite media for microwave shields. Proceedings of the 2006 IEEE International Symposium on Electromagnetic Compatibility (EMC 2006), August 14-18, 2006, IEEE, Portland, USA., pp: 6-10.

Kombaiah, K., J.J. Vijaya, L.J. Kennedy, M. Bououdina and K. Kaviyarasu et al., 2017. Effect of $\mathrm{Cd}^{2+}$ concentration on $\mathrm{ZnFe}_{2} \mathrm{O}_{4}$ nanoparticles on the structural, optical and magnetic properties. Opt., 135: 190-199.

Mahafza, B.R., 2013. Radar Systems Analysis and Design Using MATLAB. 3rd Edn., CRC Press Publishing Company, Boca Raton, Florida, USA., ISBN-13:9781439884959, Pages: 751. 
Mutar, M.A., 2010. A study in vulcanization of neoprene rubber (WRT) by polymethylol resin (RESOL). J. Al Nahrain Univ. Sci., 13: 1-6.

Shtarkova, R. and N. Dishovsky, 2009. Elastomer-based microwave absorbing materials. J. Elastomers Plast., 41: 163-174.

Sindhu, S., M.R. Anantharaman, B.P. Thampi, K.A. Malini and P. Kurian, 2002. Evaluation of a.c. conductivity of rubber ferrite composites from dielectric measurements. Bull. Mater. Sci., 25: 599-607.
Spaldin, N.A., 2010. Magnetic Materials: Fundamentals and Applications. 2nd Edn., Cambridge University Press, Cambridge, UK., ISBN-13:978-0521886697, Pages: 290.

Winspear, G.G., 1968. The Vanderbilt Rubber Handbook. RT Vanderbilt Co. Inc., USA.

Zhao, C., W. Huang, X. Liu, S.W. Or and C. Cui, 2016. Microwave absorbing properties of $\mathrm{NiFe}_{2} \mathrm{O}_{4}$ nanosheets synthesized via. a simple surfactant-assisted solution route. Mater. Res., 19: 1149-1154. 